Tropical Journal of Pharmaceutical Research October 2020; 19 (10): 2219-2225

ISSN: $1596-5996$ (print); 1596-9827 (electronic) (C) Pharmacotherapy Group, Faculty of Pharmacy, University of Benin, Benin City, 300001 Nigeria

\title{
Pharmacoepidemiological assessment of off-label drug use in pediatric ambulatory departments at four tertiary care hospitals in Pakistan
}

\author{
Rabeea Sharif ${ }^{1}$, Muhammad Aamir ${ }^{2}$, Faisal Shakeel ${ }^{3}$, Shah Faisal ${ }^{4}$, Jamshaid \\ Ali Khan ${ }^{1}$ \\ ${ }^{1}$ Department of Pharmacy, University of Peshawar, ${ }^{2}$ Department of Pharmacy, Sarhad University of Science and Information \\ Technology, Peshawar, Pakistan, ${ }^{3}$ College of Clinical Pharmacy, University of Michigan, USA, ${ }^{4}$ Department of Pharmacy, \\ University of Malakand, Chakdara, Pakistan
}

*For correspondence: Email: jamshaidkhan@uop.edu.pk

Sent for review: 6 February 2020

Revised accepted: 15 September 2020

\begin{abstract}
Purpose: To assess the frequency and possible predictors of off-label drug use in ambulatory pediatric units of four tertiary healthcare institutions in a Pakistani city.

Methods: A prospective study was conducted at the pediatric ambulatory department of four tertiary care hospitals of Peshawar, Pakistan. A total 1589 patients were included in the study which to evaluate their prescriptions for off-label drug use with the aid of Thomson Healthcare Micromedex DRUGDEX database.

Results: A total of 79 different drugs were prescribed 5668 times to pediatric patients. A high rate of offlabel drug use (71.8\%) was observed in this study. Compared to corresponding reference categories, infants (OR 4.134, $95 \%$ Cl 2.076-8.235) and children (OR 1.857, $95 \%$ Cl 0.967-3.568) were more likely to receive off-label prescriptions. However, pediatric patients receiving less than four drugs (OR $0.414,95 \% \mathrm{Cl}$ 0.312-0.548) were less likely to receive off-label prescriptions.

Conclusion: A high incidence of off-label drug use has been observed in the ambulatory pediatric population studied, especially in infants. More research is needed to identify and evaluate the contributory factors to off-label use of drugs in ambulatory pediatric population in developing countries to achieve optimal drug therapy for pediatrics.
\end{abstract}

Keywords: Pediatric population, Ambulatory, Off-label drug use

\begin{abstract}
This is an Open Access article that uses a funding model which does not charge readers or their institutions for access and distributed under the terms of the Creative Commons Attribution License (http://creativecommons.org/licenses/by/4.0) and the Budapest Open Access Initiative (http://www.budapestopenaccessinitiative.org/read), which permit unrestricted use, distribution, and reproduction in any medium, provided the original work is properly credited.

Tropical Journal of Pharmaceutical Research is indexed by Science Citation Index (SciSearch), Scopus, International Pharmaceutical Abstract, Chemical Abstracts, Embase, Index Copernicus, EBSCO, African Index Medicus, JournalSeek, Journal Citation Reports/Science Edition, Directory of Open Access Journals (DOAJ), African Journal Online, Bioline International, Open-J-Gate and Pharmacy Abstracts
\end{abstract}

\section{INTRODUCTION}

Rational Pediatric pharmacotherapy is a challenging endeavour to clinicians. Most of the drugs prescribed to pediatrics do not have established safety and efficacy data because of lack of sufficient clinical drug trials in this population to date [1]. Many factors contribute to the absence of clinical trial based data e.g. patient recruitment, consent problems, lack of previous knowledge about the long term toxic effects of a drug, different pharmacokinetic and pharmacodynamic profile of children [2]. Due to these reasons, data from adult studies is 
extrapolated for drugs to use in children that may be inappropriate. This lack of clinical knowledge of drugs for children has elicited the off-label drug use which contribute to the overall increase in the risk of harm to this particular age group [3].

Off label prescribing is an extensive global practice in pediatric pharmacotherapy. About 80 $\%$ of approved drugs are not labeled for use in children in United States [4]. According to Food and Drug Administration off label drug use is the use of a drug at a dose, medical condition, age or method of administration which is not in accordance with information labeled on product license of the drug.

Many drugs have been found to be used in off label manner that lead to inappropriate drug therapy such as salbutamol and cetirizine used in dose higher than recommended doses, montelukast used to treat perennial allergic rhinitis which is not a labeled indication. The use of promethazine under 2 years of children may cause respiratory depression and death [5].

Most of the studies addressing the use of off label drugs in pediatric population were hospital based though this setting does represent pediatrics with small proportion of risk of adverse drug reactions [6]. A very few studies have been reported in ambulatory pediatric department and most of the work related to dose, safety and efficacy have been insufficiently documented. Therefore, careful evaluation of pediatric pharmacotherapy in terms of proper drug selection, its proper dosage, age appropriateness and right formulation is a need of the day [7].

Currently no studies have been undertaken on prevalence of off label use of drugs in ambulatory pediatric population in our county. This inceptive study will facilitate to scrutinize the extent and frequency of off label use of drugs in ambulatory pediatric population in association to their predictors.

\section{METHODS}

A prospective, cross-sectional study was conducted at two public [Hayatabad Medical Complex (HMC) and Khyber Teaching Hospital $(\mathrm{KTH})$ ] and two private [Northwest General Hospital and Research Center (NWGHRC) and Rehman Medical Institute (RMI)] hospitals located at Peshawar city, Khyber Pakhtunkhwa, Pakistan. These four hospitals are leading hospitals of province and have been offering comprehensive range of health care services to individuals with aim to raise long term health status of the community. The study was undertaken at pediatric ambulatory departments over a period of January 2017 to December 2017. Sample size was determined by the formula for known populations [8]. In order to collect data simple random sampling technique was employed. Data of 1589 patients were obtained from all hospitals. In order to get access to the patient data of each hospital, approval was granted from their ethical committees. Confidentiality of patient prescription data was strictly maintained. The study was in compliance with the International Conference Harmonization Good Clinical Practice guidelines [9].

After obtaining Ethical approval from hospitals the patient information was retrieved from prescriptions which includes patient demographics (age, gender, identification number, diagnosis and date of visit), detail of the medication prescribed (dosage form, dose, frequency, route of administration and duration of therapy). Generic of the drugs were obtained from Drug Manual and Pharmaguide 20th edition of Pakistan as prescription by trade name of drug was observed during collection of data. Off label drug use were evaluated for age, dose, indication and administration form by using Thomson Healthcare Micromedex DRUGDEX database [10]. The study included patients of either gender with age under 18 years attending pediatric outpatient department. Herbal drugs and topical preparations were excluded from study. The International Classification of Diseases 11 was used to classify the diseases of patients [11]. The prescribed drugs were classified using Anatomical Therapeutic Chemical Classification System [12].

\section{Data analysis}

For analyzing data IBM SPSS Statistics for windows, version 20 (Armonk, NY: IBM corp.) was used. Demographic data of patients including age, gender and diagnosis were presented as frequencies, mean and standard deviation. Univariate and multivariate binary logistic regression was used to calculate the odd ratio with $95 \%$ confidence interval $(\mathrm{Cl})$ for the predictors of off label use of drug.

\section{RESULTS}

From both government \& private tertiary care hospital sample of 1589 patients were included. Male population was predominant over female (59.9 \%). Age groups were categorized according to WHO (World Health Organization) guidelines [13]. The median age of the population was 36 months while median of 
number of prescribed drugs was 3 . The patient characteristics are given in Table 1.

Most ubiquitous diagnosis found were pharyngitis (29.8\%), bronchitis (22.5\%), protozoal intestinal disease unspecific (12.8\%), tonsillitis (8.1\%), allergic rhinitis (7.3 \%), asthma (4.2\%), oesophagitis $(3.5 \%)$, nasopharyngitis $(2.8 \%)$, sinusitis $(1.6 \%)$, Protein-energy malnutrition of moderate and mild degree $(1.3 \%)$. The patient morbidities are given in Table 1.

Anti-bacterial for systemic use $(21.7 \%)$, antihistamines for systemic use (15.6\%), drugs for obstructive airway diseases (15.3\%), antiinflammatory and anti-rheumatic drugs (10.4\%), analgesic drugs (10.1\%), anti-protozoal drugs (5 $\%)$, vitamins $(4.4 \%)$, miscellaneous (4.1\%), cough and cold drugs (3.6\%) and anti-anemic $(3.0 \%)$ were the most prevalent therapeutic drug classes. Most commonly prescribed drugs to the patients were paracetamol $(9.9 \%)$, ibuprofen (8.7\%), cefixime $(6.1 \%)$, amoxicillin/clavulanic acid (5.4 \%), chlorpheniramine (4.3\%), montelukast (4\%), multivitamins (4\%), cetirizine
(3.8 \%), metronidazole (3.2 \%) and albuterol (3.2 $\%)$. Drug used as off-label was $71.8 \%$ in pediatric patients. Patients received at least oneoff label drug were 566 (35.6\%). In off label categories age $(40.2 \%)$ and dose $(27.5 \%)$ were most recurrent categories in all therapeutic classes. Other categories of off label were ageindication $(20.7 \%)$, dose-age $(5.7 \%)$, age-doseindication $(3.7 \%)$, dosage form (1.1\%), agedosage form (15\%) and dose-dosage form (0.1 $\%)$. Most frequently prescribed drugs as off-label and their off-label categories are given in Table 2. Pediatric age variable is compared with reference to frequently prescribed off label drugs in Figure 1.

A significant association was found between type of hospitals and off label drug use $(p<0.0001)$ by applying chi square test. In comparison between government \& private hospitals drug use as off-label was more prevalent in private hospitals, i.e. in private healthcare setup NWGH it was $88.0 \%$ and in RMI it was $78.5 \%$ while in government hospitals $\mathrm{HMC}$ it was $56.3 \%$ and in $\mathrm{KTH}$ it was $53.9 \%$.

Table 1: Patient characteristics and morbidities

\begin{tabular}{|c|c|c|c|c|c|}
\hline Variable & $\begin{array}{l}\text { Frequency } \\
\text { NWGH (\%) }\end{array}$ & $\begin{array}{c}\text { Frequency } \\
\text { RMI (\%) }\end{array}$ & $\begin{array}{c}\text { Frequency } \\
\text { HMC (\%) }\end{array}$ & $\begin{array}{c}\text { Frequency } \\
\text { KTH (\%) }\end{array}$ & Total \\
\hline \multicolumn{6}{|l|}{ Age (months) } \\
\hline Infant $\geq 23$ & $165(10.4)$ & $160(10.1)$ & $98(6.2)$ & $65(4.1)$ & $488(30.7)$ \\
\hline Children 24-143 & $228(14.3)$ & $220(13.8)$ & 296(18.6) & $311(19.6)$ & $1055(66.4)$ \\
\hline Adolecent $\geq 144$ & $16(1.0)$ & $6(0.4)$ & $7(0.4)$ & $17(1.1)$ & $46(2.9)$ \\
\hline Total & $409(25.8)$ & $386(24.3)$ & $401(25.2)$ & $393(24.7)$ & $1589(100)$ \\
\hline Mean $\pm S D$ & $41.5 \pm(39.1)$ & $37.5 \pm(34.0)$ & $45.6 \pm(34.9)$ & $60.4 \pm(39.2)$ & $46.3 \pm(37.9)$ \\
\hline \multicolumn{6}{|l|}{ Gender } \\
\hline Male & $267(16.8)$ & $262(16.5)$ & $220(13.8)$ & 203(12.8) & $952(59.9)$ \\
\hline Female & $142(9.0)$ & $124(7.8)$ & $181(11.4)$ & $190(11.9)$ & $637(40.1)$ \\
\hline Total & $409(25.8)$ & $386(24.3)$ & $401(25.2)$ & $393(24.7)$ & $1589(100)$ \\
\hline \multicolumn{6}{|l|}{ Prescribed drugs } \\
\hline $1(1-3)$ & $176(11.1)$ & $244(15.3)$ & $319(20.1)$ & 294(18.5) & $1033(65.0)$ \\
\hline $2(\geq 3)$ & $233(14.7)$ & $142(9.0)$ & $82(5.1)$ & $99(6.2)$ & $556(35.0)$ \\
\hline Total & $409(25.8)$ & $386(24.3)$ & $401(25.2)$ & $393(24.7)$ & $1589(100)$ \\
\hline Mean $\pm S D$ & $3.7 \pm(1.0)$ & $3.2 \pm(0.9)$ & $3.0 \pm(0.6)$ & $3.0 \pm(0.7)$ & $3.2 \pm(0.9)$ \\
\hline Range & $2-7$ & $2-6$ & $2-5$ & $2-5$ & $2-7$ \\
\hline \multicolumn{6}{|l|}{ Diagnosis(ICD codes) } \\
\hline Pharyngitis ( $\mathrm{J02}$ ) & $90(5.7)$ & $122(7.7)$ & $153(9.6)$ & $108(6.8)$ & $473(29.8)$ \\
\hline Bronchitis (J20) & $34(2.1)$ & $25(1.6)$ & $156(9.8)$ & $142(8.9)$ & $357(22.5)$ \\
\hline $\begin{array}{l}\text { Protozoal intestinal } \\
\text { disease unspecific } \\
\text { (A07.9) }\end{array}$ & $57(3.6)$ & $51(3.2)$ & $53(3.3)$ & $43(2.7)$ & $204(12.8)$ \\
\hline Tonsillitis (J03) & $45(2.8)$ & $22(1.4)$ & 18(1.1) & $43(2.7)$ & $128(8.1)$ \\
\hline Allergic rhinitis (J30) & $46(2.9)$ & $68(4.3)$ & $1(0.1)$ & $1(0.1)$ & $116(7.3)$ \\
\hline Asthma (J45) & $19(1.2)$ & $46(2.9)$ & $1(0.1)$ & $1(0.1)$ & $67(4.2)$ \\
\hline Esophagitis (K20) & $31(2.0)$ & $11(0.7)$ & $4(0.2)$ & $10(0.6)$ & $56(3.5)$ \\
\hline Nasopharyngitis ( $\mathrm{J} 00)$ & $15(.9)$ & $25(1.6)$ & $1(0.1)$ & $3(0.2)$ & $44(2.8)$ \\
\hline Sinusitis (J32) & $1(0.1)$ & $1(0.1)$ & $0(0)$ & $23(1.4)$ & $25(1.6)$ \\
\hline $\begin{array}{l}\text { Protein-energy } \\
\text { malnutrition of } \\
\text { moderate and mild } \\
\text { degree } \\
\text { (E44) }\end{array}$ & $18(1.1)$ & $1(0.1)$ & $0(0)$ & $1(0.1)$ & $20(1.3)$ \\
\hline
\end{tabular}


Table 2: Most frequently prescribed off-label drugs with their off-label categories

\begin{tabular}{|c|c|c|c|c|c|c|c|c|c|}
\hline Generic & Age & Dose & $\begin{array}{l}\text { Dosage } \\
\text { form }\end{array}$ & $\begin{array}{c}\text { Age, } \\
\text { indication }\end{array}$ & $\begin{array}{l}\text { Age, } \\
\text { dose }\end{array}$ & $\begin{array}{c}\text { Age, } \\
\text { dosage } \\
\text { form }\end{array}$ & $\begin{array}{c}\text { Dose, } \\
\text { dosage } \\
\text { form }\end{array}$ & $\begin{array}{l}\text { Age, dose, } \\
\text { indication }\end{array}$ & Total \\
\hline Cefixime & 13 & 90 & 0 & 121 & 4 & 0 & 0 & 2 & 230 \\
\hline Chlorpheniramine & 154 & 3 & 0 & 0 & 58 & 0 & 0 & 0 & 215 \\
\hline Iron polymaltose & 0 & 1 & 0 & 135 & 0 & 0 & 0 & 29 & 165 \\
\hline Dextromethrophan & 90 & 56 & 0 & 0 & 0 & 0 & 0 & 0 & 146 \\
\hline Albuterol & 79 & 0 & 7 & 0 & 0 & 17 & 0 & 0 & 103 \\
\hline Levocetirizine & 54 & 42 & 0 & 0 & 0 & 0 & 0 & 0 & 96 \\
\hline Domperidone & 0 & 92 & 0 & 0 & 0 & 0 & 2 & 0 & 94 \\
\hline Triprolidine & 57 & 3 & 0 & 0 & 22 & 0 & 0 & 0 & 82 \\
\hline Pseudoephedrine & 59 & 1 & 13 & 0 & 0 & 2 & 0 & 0 & 75 \\
\hline Ipratropium bromide & 0 & 0 & 0 & 70 & 0 & 0 & 0 & 0 & 70 \\
\hline
\end{tabular}

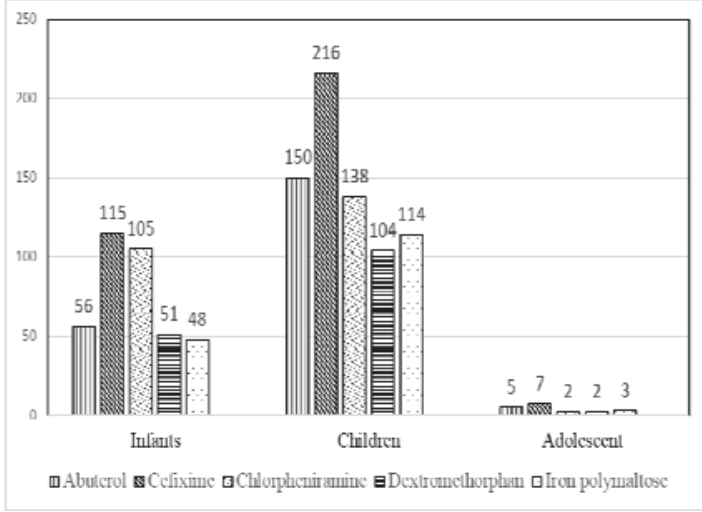

Figure 1: Comparison of age groups with respect to most prevalent off label drugs

There was significant association between the age groups $\&$ off label drug $(p<0.0001)$. Offlabel use of drugs was prevalent more in children $44.2 \%(702 / 1589)$ and infants $25.9 \%$ (413/1589).

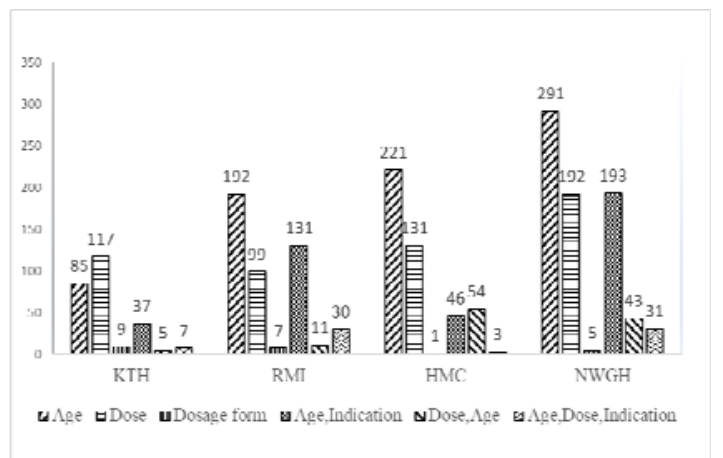

Figure 2: Comparison of hospitals with regard to frequency of off-label drug categories

While according to univariate and multivariate logistic regression insignificant association were found between gender \& drug use on off label basis. We consider gender as an insignificant predictor of off-label use of drug because multivariate logistic regression is more precise and accurate tool than chi square test.

Univariate logistic regression analysis shows that pediatric patients of age 0-23 months (OR 4.236, $95 \% \mathrm{Cl} 2.250-7.975)$ were significantly more likely to receive off label drugs than adolescent. Similarly, patients receiving less than 4 drugs (OR 0.333, $95 \%$ Cl 0.256-0.434) were significantly less likely to receive off-label drugs as compared to patients receiving 4 or more drugs. NWGH (OR 0.268, $95 \% \mathrm{Cl} 0.186-0.386$ ), RMI (OR 0.159, $95 \% \mathrm{Cl} 0.111-0.228$ ) and HMC (OR 0.497, $95 \%$ Cl 0.338-0.730) were significantly less likely to receive off label drugs as compared to $\mathrm{KTH}$.

Multivariate logistic regression analysis shows that pediatric patients of age $0-23$ months (OR $4.134,95 \% \mathrm{Cl} 2.076-8.235)$ and of age 24-143 months (OR 1.857, $95 \% \mathrm{Cl}$ 0.967-3.568) were significantly more likely to receive off label drugs than adolescent. Similarly, patients receiving less than 4 drugs (OR $0.414,95 \% \mathrm{Cl} 0.312-0.548$ ) were significantly less likely to receive off-label drugs as compared to patients receiving 4 or more than 4 drugs. Hospitals such as NWGH (OR 0.388, $95 \% \mathrm{Cl}$ 0.265-0.569), RMI (OR $0.231,95 \% \mathrm{Cl} 0.159-0.336$ ) and HMC (OR $0.550,95 \% \mathrm{Cl} 0.370-0.818$ ) were significantly less likely to receive off-label drugs as compared to KTH. Off-label use of drugs according to univariate and multivariate logistic regression are given in Table 3.

\section{DISCUSSION}

Drug use as off label was widely observed in pediatric ambulatory population. This study underlines high rate of off label use of drugs $(71.8 \%)$ as compared to report published in France (29\%) [14]. A French study revealed 42 $\%$ off label use of drugs in pediatric ambulatory department [15]. Other studies performed in 
Table 3: Predictors of off-label drug use

\begin{tabular}{|c|c|c|c|c|}
\hline \multirow[t]{2}{*}{ Variable } & \multicolumn{2}{|c|}{ Univariate analysis } & \multicolumn{2}{|c|}{ Multivariate analysis } \\
\hline & $\mathrm{OR}(95 \% \mathrm{Cl})$ & Significance & OR(95\% Cl) & Significance \\
\hline \multicolumn{5}{|l|}{ Gender } \\
\hline Female & $1.33(1.068-1.663)$ & 0.11 & $1.147(0.904-1.457)$ & 0.259 \\
\hline Male & Reference & & Reference & \\
\hline \multicolumn{5}{|l|}{ Age } \\
\hline Infant & $4.236(2.250-7.975)$ & $0.000^{* * *}$ & $4.134(2.076-8.235)$ & $0.000^{* * *}$ \\
\hline Children & $1.530(0.842-2.778)$ & 0.16 & $1.857(0.967-3.568)$ & $0.063^{*}$ \\
\hline Adolescent & Reference & & Reference & \\
\hline \multicolumn{5}{|c|}{ Prescribed drugs } \\
\hline $1(<4)$ & $0.333(0.256-0.434)$ & $0.000^{* * *}$ & $0.414(0.312-0.548)$ & $0.000^{* * *}$ \\
\hline $2(\geq 4)$ & Reference & & Reference & \\
\hline \multicolumn{5}{|l|}{ Hospitals } \\
\hline NWGHRC & $0.268(0.186-0.386)$ & $0.000^{* * *}$ & $0.388(0.265-0.569)$ & $0.000^{* * *}$ \\
\hline$R M I$ & $0.159(0.111-0.228)$ & $0.000^{* * *}$ & $0.231(0.159-0.336)$ & $0.000^{* * *}$ \\
\hline$H M C$ & $0.497(0.338-0.730)$ & $0.000^{* * *}$ & $0.550(0.370-0.818)$ & $0.003^{* *}$ \\
\hline$K T H$ & Reference & & Reference & \\
\hline
\end{tabular}

Germany from 2003-2006 showed $40.2 \%$ of offlabel use of drugs [16]. While studies performed in United States, Estonia and Sweden also reported a high rate of off label use of drug from 13.5 to $62 \%[1,5,14]$. This variability in rate of off label use of drugs may be on account of different drug authorization status for pediatric use in different region as well as lack of data on dose and indication for specific age group of children in essential drug lists of respective region. In the study drug use as off label was less prevalent in government than private healthcare setups. This difference is due to variation in morbidities and different prescribing practice in hospitals. In this study $35.6 \%$ patients received at least one offlabel drug which was much lower when compared to the Swedish study (64\%) [1]. This variability is probably due to different types of off label drug categories considered in the different studies.

We have analyzed off label use of drug in relation to age of pediatrics and found high prevalence of off label drug use in children and infants. Reports from studies performed in France also revealed similar high proportion of off labeling in children $23.1 \%$, infant $18.8 \%$ and adolescent $16.8 \%$ [14]. There was significant relationship found between infant and children age group and off label use of drugs. Other studies performed in USA, Malta and Spain also showed high percentage of off label use of drugs in children and infants $[5,17,18]$.

In this study age and dose were the common were the common reason for off label drug use, study conducted in USA in an outpatient sitting reported the same reason [5]. In contrast to other studies slightly different reasons have been found. A Spanish study conducted in pediatric gastroenterology outpatient had revealed that indication (82\%) and dose $(17.3 \%)$ were the main causes for the drug use as off label [18]. Alike study in France reported indication and dose as most prevalent off label drug use categories [15]. An Irish study has showed dose $63.3 \%$ as most prevalent off label drug use category followed by age $34.3 \%$ [19]. Many studies revealed dose as most common off label category in outpatient setting [20,21]. Another study has also reported dose as the major cause for drug use as off label followed by indication. When compared to other researches, dose was common among all off label drug categories. The reason could be lack of clinical trials in children for their dose estimation which have not been covered by summary of product characteristics and for same reason not reported in Micromedex DRUGDEX database.

Antibacterial for systemic use $(21.7 \%)$ and Anti histamine for systemic use were the most frequently prescribed therapeutic drug class in accordance with Swedish and Irish studies conducted on ambulatory pediatric clinics $[1,19]$. Another study conducted in US also observed concurrent findings[5]. An Italian study showed anti-bacterial for systemic use and drugs for alimentary tract as most common prescribed drug classes [22]. Similarly, evidence from other studies, report anti-bacterial for systemic use and anti-histamine for systemic use as most prevalent therapeutic drug class [19]. A pharmacovigilance survey in France on 1419 patients also report anti-bacterial for systemic use as most commonly prescribed drug class.[15]. A high prevalence of anti-bacterial and anti-histamine in pediatric population might be due to exposure to microbial infections and most of drugs under these therapeutic drug classes were not labeled for pediatrics. 
In our study the most commonly drugs prescribed were ibuprofen and acetaminophen in concordance with other studies [14,20]. Similarly, Lifshitz et al conducted a study at Israel which revealed amoxicillin in addition to acetaminophen as most prevalent prescribed drugs to pediatrics [19]. Kazouini et al analyzed prescribing of acetaminophen in Scottish children and found it typically prescribed as an off label drug [16]. Acetaminophen is not licensed for children under 2 months of age in British National Formulary [23] and according to Micromedex DRUGDEX database in children having age under 2 years the use of acetaminophen is not suggested.

In this study, there was positive and significant relationship between off label drug use and age. Patients in younger age groups (infants and children) were significant predictor for the use of drug as off label as demonstrated by other studies [20,21,24]. Another significant positive predictor for the use of drug as off label in the current study was patients receiving 3 or less than 3 drugs. A similar finding has been reported by many other studies $[5,15,21]$. There was no significant correlation between gender and off label drug use like many other studies [15,24]. The reason behind this may be that no consideration is given to the gender during drug development processes.

The adverse effects of drug also increasing due to prescribing drugs in off label manner. It is noted that because of off label drug use $17 \%$ adverse drug reaction occurs [18]. Therefore, certain measures have been taken to improve pediatric pharmacotherapy. An example is the launching of pediatric regulations for the purpose of improving the health of the children [7]. Many legislations including the Pediatric Research Equity Act of 2003, the best Pharmaceuticals for children Act of 2002, the pediatric exclusivity component of the Food and Drug Modernization Act of 1997, the Food and Drug Administration Amendments Act and European Union regulations 2007 are appreciable but more incentives and funds are required to conduct clinical drug trials on pediatrics to achieve unmet therapeutic requirements of children. Still more than 400 products have not been formally analyzed in children [7].

The high level of off label use of drug in children suggested that further clinical researches are required to find out the reasons for the use of drug in off label manner. Gazarian et al described that many prescribers believed that off label use of drugs is legal where benefits overweigh risks. However, it should not be recommended since adequate knowledge of true balance between risk and benefit is unknown that may lead to adverse effects. [21]. Clinical trials should not be done only for new drugs but also for already available drugs in the market currently used as off label. It is also recommended that upon new information on literature of the product should be made available and updated time to time by the regulatories in order to ensure children are not exposed to unnecessary risks and provide them with approved evidenced based therapy.

This current study analyzed off-label use of drug only in pediatric ambulatory population in tertiary care system, off label drug use should also be monitored in other ambulatory departments. In addition, it should be extended to primary health care system.

\section{Limitations of the study}

The study was specifically conducted in pediatrics ambulatory departments of tertiary care hospitals, it does not reflect the trends of off-label use of drugs in other departments of hospitals in Pakistan. The results of study need to be generalized with caution in population. Electronic medical records were not available that's why study took time.

\section{CONCLUSION}

This study has reported a higher rate of off label use of drug in ambulatory pediatrics. To the best of our knowledge, no such study has recognized this problem in ambulatory pediatric in our country. In order to avoid pediatrics from exposing to unnecessary risk researchers should target those unstudied drugs that accounts for off label prescribing. It is important that new ways and strategies should be established by national and international authorities to ensure safe and effective evidence-based pediatric pharmacotherapy.

\section{DECLARATIONS}

\section{Acknowledgement}

The authors acknowledge the support of Directorate of Science and Technology (DoST), Khyber Pakhtunkhwa, Pakistan for the provision of Micromedex database.

\section{Conflict of interest}

No conflict of interest is associated with this work. 


\section{Contribution of authors}

We declare that this work was done by the authors named in this article and all liabilities pertaining to claims relating to the content of this article will be borne by the authors.

\section{Open Access}

This is an Open Access article that uses a funding model which does not charge readers or their institutions for access and distributed under the terms of the Creative Commons Attribution License (http://creativecommons.org/licenses/by/ 4.0) and the Budapest Open Access Initiative (http://www.budapestopenaccessinitiative.org/rea d), which permit unrestricted use, distribution, and reproduction in any medium, provided the original work is properly credited.

\section{REFERENCES}

1. Olsson J, Kimland E, Pettersson S, Odlind V. Paediatric drug use with focus on off-label prescriptions in Swedish outpatient care-a nationwide study. ACTA PAEDIATR 2011; 100 (9) : 1272-1275.

2. Clavenna A, Bonati M. Drug prescriptions to outpatient children: a review of the literature. Eur $J$ Clin Pharmacol 2009; 65 (8) : 749-755.

3. Morales-Carpi C, Estan L, Rubio E, Lurbe E, MoralesOlivas FJ. Drug utilization and off-label drug use among Spanish emergency room paediatric patients. Eur J Clin Pharmacol 2010; 66 (3) : 315-320.

4. Tobin JR. Use of pharmaceuticals Off-Label in the neonate. Best Pract Res Clin Anaesthesiol 2010; 24 (3) :451-460.

5. Bazzano AT, Mangione-Smith $R$, Schonlau M, Suttorp $M J$, Brook RH. Off-label prescribing to children in the United States outpatient setting. ACAD PEDIATR 2009; 9 (2) : 81-8.

6. Al Khaja KA, Al Ansari TM, Damanhori AH, Sequeira RP. Evaluation of drug utilization and prescribing errors in infants: a primary care prescription-based study. HEALTH POLICY 2007; 81 (2-3) : 350-357.

7. Chai G, Governale L, McMahon AW, Trinidad JP, Staffa $J$, Murphy $D$. Trends of outpatient prescription drug utilization in US children, 2002 2010. Pediatrics-Engl Edn. 2012; 130 (1) : 23.

8. Daniel J. Sampling essentials: Practical guidelines for making sampling choices: Sage; 2011.

9. Williams JR. The Declaration of Helsinki and public health. Bulletin of the World Health Organization. 2008; $86: 650-652$.

10. Czaja AS, Valuck R. Off-label antidepressant use in children and adolescents compared with young adults: extent and level of evidence. Pharmacoepidemiol Drug Saf 2012; 21 (9) : 997-1004.
11. Reed GM, Drescher J, Krueger RB, Atalla E, Cochran SD, First MB, Cohen-kettenis PT, Montis IA, Parish SJ, Cottler $S$ et al. Disorders related to sexuality and gender identity in the ICD-11: revising the ICD-10 classification based on current scientific evidence, best clinical practices, and human rights considerations. World Psychiatry 2016; 15 (3): 205-221.

12. Organization WH. The anatomical therapeutic chemical classification system with defined daily doses (ATC/DDD). Oslo: WHO. 2006.

13. Knoppert D, Reed M, Benavides S, Totton J, Hoff D, Moffett $B$, Norris K, Vaillancourt $R$, Aucoin $R$ and Worthington. Paediatric age categories to be used in differentiating between listing on a model essential medicines list for children. WHO Position Paper 2007; 15.

14. Palmaro A, Bissuel R, Renaud N, Durrieu G, Escourrou B, Oustric S, Montastruc JL, Lapeyre-Mestre M. Offlabel prescribing in pediatric outpatients. Pediatrics 2015; 135 (1) : 49-58.

15. Horen B, Montastruc J-L, Lapeyre-Mestre M. Adverse drug reactions and off-label drug use in paediatric outpatients. Br J CliN PharmacoL 2002; 54 (6) : 665.

16. Knopf $H$, Wolf I-K, Sarganas G, Zhuang W, Rascher W, Neubert A. Off-label medicine use in children and adolescents: results of a population-based study in Germany. BMC Public Health 2013; 13 (1) : 631.

17. Ellul IC, Grech V, Attard-Montalto S. Paediatric off-label and unlicensed prescribing in primary care in Malta: Prospective observational drug utilisation study. Int $J$ Risk Saf Med 2015; 27 (3) : 123-134.

18. Ruiz-Antoran B, Pineiro R, Avendano C, Roman E, Cilleruelo ML, Gutierrez-Junquera C, Centeno $G$ and Jose Cilleruelo M. Drug utilization and off-label drug use in Spanish pediatric gastroenterology outpatients. J PEDIATR GASTR NUTR 2013; 56 (2) : 173-177.

19. Lifshitz M, Gavrilov V, Grossman Z, Binsthok M, Hornik $D$, Rosemblum H, Chemni S, Alkrinawi S, Miron D and Gorodischer. Unapproved prescription practices in primary pediatric clinics in Israel: a prospective analysis. CURR THER RES E 2002; 63 (12) : 830-837.

20. Bhadiyadara SN, Rana DA, Malhotra SD, Patel VJ. Offlabel and Unlicensed Drug Use in Paediatric Outpatient Department-A Prospective Study at a Tertiary Care Teaching Hospital. J Young Pharm 2015; 7 (3) : 164.

21. Silva D, Ansotegui I, Morais-Almeida M. Off-label prescribing for allergic diseases in children. WORLD ALLERGY ORGAN 2014; 7 (1):1.

22. Carnovale C, Conti V, Perrone V, Antoniazzi S, Pozzi M, Merlino $L$, Venegoni $M$, Clementi $E$, Radice $S$. Paediatric drug use with focus on off-label prescriptions in Lombardy and implications for therapeutic approaches. Eur J Pediatr 2013; 172 (12) : 1679-1685.

23. Britain RPSoG. British national formulary: Pharmaceutical Press; 2012.

24. Langerova $P$, Vrtal J, Urbanek K. Incidence of unlicensed and off-label prescription in children. Ital J Pediatr 2014; $40(1): 12$.

Trop J Pharm Res, October 2020; 19(10): 2225 